\section{EMBRYRIDDLE}

Aeronautical University

SCHOLARLY COMMONS
Journal of Aviation/Aerospace

Education \& Research

Volume 8

Number 1 JAAER Fall 1997

Article 7

Fall 1997

\title{
Student and Instructor Perceptions of Effective Instructional Methods in a University Aviation Human Factors Course
}

Lorelie E. Miller

Jose R. Ruiz

Susan E. Sharp

sharps@erau.edu

Follow this and additional works at: https://commons.erau.edu/jaaer

\section{Scholarly Commons Citation}

Miller, L. E., Ruiz, J. R., \& Sharp, S. E. (1997). Student and Instructor Perceptions of Effective Instructional Methods in a University Aviation Human Factors Course. Journal of Aviation/Aerospace Education \& Research, 8(1). https://doi.org/10.15394/jaaer.1997.1215

This Article is brought to you for free and open access by the Journals at Scholarly Commons. It has been accepted for inclusion in Journal of Aviation/Aerospace Education \& Research by an authorized administrator of Scholarly Commons. For more information, please contact commons@erau.edu. 


\title{
STUDENT AND INSTRUCTOR PERCEPTIONS OF EFFECTIVE INSTRUCTIONAL METHODS IN A UNIVERSITY AVIATION HUMAN FACTORS COURSE
}

\author{
Lorelei E. Miller, Jose R. Ruiz, and Susan E. Sharp
}

Aviation human factors instructors employed by University Aviation Association (UAA) member institutions and aviation flight students from Southern Illinois University at Carbondale (SIUC) were asked to rank nine teaching methods according to perceived effectiveness in each of four subject areas: flight physiology, flight psychology, aeronautical decision-making (ADM), and crew resource management (CRM). Responses were compiled into two categories, students and instructors. Analysis using the Spearman's rank correlation coefficient indicated that students and instructors generally agreed on teaching methods they considered appropriate to the four subject areas.

\section{INTRODUCTION}

Since the first aircraft took to the skies, aviators have been concerned with the interface between the human element and the unique characteristics of the flight environment. The study of aviation human factors and the impact that it poses on the safety of flight operations is a topic of exhaustive research in the aviation community. A variety of teaching methodologies and media, including lecture, guided group discussion, role-play, and simulations, are often used in the delivery of human factors instruction. This study was conducted in an effort to identify effective methods of instructional delivery to be incorporated in the development of an introductory-level aviation human factors course. By surveying instructor and student perceptions of various teaching methods, this study suggests instructional strategies that could be used.

\section{PURPOSE OF THE STUDY}

The purpose of this study was to determine effective instructional methods for an introductory aviation human factors course at SIUC. In 1996, the SIUC flight department was charged with developing a new course titled Human Factors for Aviators (AF 210). Instructors assigned to develop the course were allowed extensive latitude but limited time to construct the course. The result was a course that was predominantly instructor-centered. In an article titled "Selecting Instructional Strategies," Weston and Cranton (1986) note:

In the instructor-centered methods, the teacher is primarily responsible for conveying information to a group of students. The direction of the communication tends to be one-way, from the instructor to the audience. The most familiar of these methods is the lecture, in which one instructor speaks directly to a group of students. The lecture is an efficient and effective method for instruction at the lower levels (knowledge and comprehension) of the cognitive domain, particularly in large classes; students are passive rather than active participants in the teaching and learning process (p. 260).

Although a lecture format may work well for certain subject matter in the course, instructors must use the most effective instructional methods available to teach all subjects in a way that will stimulate student learning. This study attempts to identify these methods.

\section{RESEARCH QUESTIONS}

The research questions of the study were:

1. What are instructors' perceptions of teaching methods used to present aviation human factors materials?

2. What are students' perceptions of teaching methods used to present aviation human factors materials?

3. What is the relationship between student and instructor perceptions of teaching methods used to present aviation human factors materials?

4. What materials and equipment do aviation human factors instructors use or feel would be useful in effectively presenting an introductory aviation human factors course? 


\section{IMPORTANCE OF THE PROBLEM}

There is general agreement that aviation human factors training benefits pilots who are willing to implement what they learn (Foushee \& Helmreich, 1988). By offering a well-rounded introductory course in aviation human factors, aviation flight programs could improve students' awareness of human factors issues and thus enhance their ability to recognize the impact an individual can have on aviation safety.

The Federal Aviation Administration in its Commercial Pilot Practical Test Standards for Airplane (FAA, 1997b) requires the applicant for a Commercial Pilot Certificate to demonstrate knowledge in such subjects as aeromedical factors (flight physiology), physiological concerns associated with night flying, and cockpit resource management. Crew resource management is not isolated as a single task to be demonstrated, but "is a set of skill competencies that must be evident in all TASKS in this practical test standards as applied to either single pilot or a crew operation" (p. 8). The FAA takes a definite stand on the importance of aviation human factors training by specifying these requirements. In fact, the Practical Test Standards for each pilot certificate and rating specify certain aviation human factors knowledge competencies to be demonstrated.

Until late 1997, the Federal Aviation Regulations (FARs) were vague in specifying human factors training subjects for general aviation pilots. According to FAR Part 141: Pilot Schools Appendix D(2)(e), a Commercial Pilot Certification Course in a Part 141 school (for example, SIUC) was to include ground training in "high altitude operations and physiological considerations" (FAA, 1997a, p. 302). No other subject matter that could be considered distinctly aviation human factors-oriented was mentioned. FAR Part 61, Certification: Pilots and Flight Instructors (FAA, 1997a), was no more helpful. This part listed specific competencies required in terms of aeronautical knowledge, proficiency, and experience. The regulations did not specify any aviation human factors training subjects for student, recreational, private, commercial, airline transport, or flight instructor certificate applicants. In late 1997, FAR Parts 61 and 141 were rewritten to include new aeronautical knowledge requirements, namely "aeronautical decision-making and judgement, and crew resource management, including crew communication and coordination" (FAA, 1998, p. 55). These 1998 FARs now require these training components to be integrated in training leading to an instrument rating, an ATP certificate, and an instrument rating on a flight instructor certificate. Training that leads to a recreational, private, commercial, or initial CFI certificate requires the integration of aeronautical decision-making and judgment training, but not crew resource management training.

According to Reinhart (1996), "human factors" means many things to many people. Engineers consider ergonomics; psychologists focus on stress management and communication; physicians consider temperature and pressure extremes; pilots think about performance in emergency situations. Ideally, an introductory aviation human factors course should address all of these aspects.

Such a course can be no more successful than its structure allows. Roscoe, Jensen, and Gawron (1980) noted that subject matter, sequence, and use of available instructional materials are the main factors behind training program efficacy. From this finding we conclude that for an aviation human factors course to deliver the desired information effectively, it is important to use the most appropriate teaching methods available for each lesson. Nickerson (1995) pointed out the need for research in human factors education in a paper prepared for the National Research Council's Committee on Human Factors. Nickerson's list of possible research areas included:

Evaluating technologically innovative approaches to education and training, applying user-centered design principles to educational and training systems, developing approaches to support lifelong learning within work settings, and anticipating technology-induced changes in job-skill requirements and their implications for educational and training needs (p. 3).

\section{INSTRUCTIONAL METHODS}

According to Davies (1981), "the ultimate goal of education and training is mastery" (p. 21). In any instructional setting, the objective of the training is to help the student develop the tools needed to function in 
a given environment. Efficiency (doing things right) and effectiveness (doing the right things) are the two qualities Davies emphasizes as being important in education. In being efficient and effective, the instructor must identify the learning needs of the students, pull together the resources to be used in the training, select appropriate methods for training, determine what motivates the students, monitor student progress, and continually work to improve the course.

Heinrich, Molenda, and Russell (1993) recommend use of the ASSURE model to help instructors provide students with a quality learning experience. This acronym stands for analyzing learners, stating objectives, selecting media and materials, using media and materials, requiring learner participation, and evaluating and revising the course objectives.

Students learn material at a series of several levels. According to the FAA's Aviation Instructor's Handbook (1977), these levels of learning (rote, understanding, application, and correlation) are the steps taken toward mastery of any given subject. Different teaching methods are needed to help students advance from one level to the next. The handbook discusses four major teaching methods used in traditional flight training: the lecture, the guided discussion, the demonstration-performance method, and programmed instruction. These methods allow for varying amounts of student involvement, from no involvement in a direct lecture to moderate involvement in the demonstration-performance method (used for specific skill acquisition).

Cooke (1987) provides a more comprehensive listing of training methods than does the FAA. In "Role Playing," a paper prepared for the American Society of Training and Development, he illustrates various training methods along a continuum from low involvement, didactic learning (reading, lecture, experiential lecture) to high involvement, experiential learning (role-playing, instrumentation, structured experience, intensive growth groups). The method used in any situation is determined by considering group maturity, facilitator skill and experience, subject matter, and the training environment. Researchers note that instructional effectiveness increases when students are more involved in the process. Archambeault (1993) stated that "problem solving is best learned in interactive situations, in which the teacher guides learners as they explore possible problem solving strategies" (p. 21).

In selecting the appropriate methods for teaching a course, several factors should be considered. Hawkins (1987) lists seven criteria to consider when selecting a training method: student preferences for learning styles, students' individual backgrounds and knowledge levels, organizational constraints, accommodation, time available, staff available, and loss of student time for productive work. Weston and Cranton (1986) state that "in curriculum design, the instructor must simultaneously consider methods, materials, the nature of the subject area, and the characteristics of the student audience" (p. 259).

Galbraith (1994) noted that enhancing a student's self-esteem opens the way for more learning to take place. One method used by Galbraith to help develop student self-esteem is to allow the learners themselves to investigate different instructional methods and to try them out. Tailoring training to the job task allows students to gain more from the learning experience. The more closely a training situation mirrors the actual performance requirements, the better the training is (Gropper \& Ross, 1987).

\section{AVIATION HUMAN FACTORS RESEARCH}

As collegiate aviation programs graduate more pilots, government and industry researchers are recognizing the contributions their programs can make to the nation's need in aviation human factors (Dismukes, 1994). Bowman (1993) found that although many universities do offer some form of aviation human factors training (the study specifically centered on pilot judgment and decision making), it is not well incorporated into existing curricula. Often, curricular constraints exist, and alreadyfull program requirements do not allow for the addition of new course work.

Several studies (Chidester, Helmreich, Gregorich, \& Geis, 1991; Helmreich \& Wilhelm, 1991) indicate that the success of aviation human factors CRM training depends heavily on flight crew members' attitudes toward such training. Instructor skill and group dynamics also are listed as factors affecting the impact of CRM training on pilots. 
Beard, Salas, and Prince (1995) suggest some guidelines for the use of structured role-play in the development of CRM skills. Their research shows that using "role-play during training can be an effective form of practice and feedback for CRM skills" (p. 141). Using a 13-step guide for developing CRM role-plays, instructors can create a learning environment in which students have the opportunity to apply the skills they are learning.

\section{RESEARCH METHODOLOGY}

Two populations were chosen for the study. Population A consisted of ground school instructors working for UAA member institutions. Population B consisted of past and current students in SIUC's Aviation Flight course AF 210 -- Human Factors for Aviators.

For Population A, a random sample of 60 UAA member institutions was selected from among the 103 member institutions. For Population B, the sample consisted of all past and present SIUC AF 210 students. The instruments used to gather data were questionnaires developed by the researchers.

\section{Instrument Design}

The instrument for Population A was developed to gather information from various university aviation instructors on resources and methods used for teaching human factors subjects to students. Part I solicits such information as instructor education level, degrees offered by the institution, aviation human factors course work offered, and texts, materials, and facilities used in teaching aviation human factors. Part II solicits instructors' preferred teaching methods and any desired equipment and/or facilities.

The instrument for Population B was developed to gather aviation flight student opinions of various teaching methods used in an aviation human factors classroom. Part I solicits such background information as flight experience and education level. Part II was designed to gather aviation flight student opinions on teaching methods used in SIUC's AF 210 course. It also was designed to determine teaching methods preferred by students.

The instruments for Populations A and B were tested and validated by administering them to members of the SIUC Aviation Management and Flight faculty and staff.
Completed questionnaires were returned to the researchers with comments.

\section{Procedure}

Cover letters were developed to accompany the survey instruments. These letters included an introductory statement describing the study, a request for the respondent's participation, and a statement of confidentiality. The cover letter for Population A included the request that copies of the instrument be made available to any flight instructor at the institution who incorporated any aviation human factors subjects in ground school courses they taught.

Population A - subjects received a pre-addressed envelope for returning the survey and a pre-addressed postcard for requesting a copy of the research findings. A follow-up letter was sent three weeks later. For Population B subjects, data were collected by distributing the student questionnaire to former AF 210 students. The survey instrument was placed in their current flight course progress chart. An impartial instructor from Aviation Flight administered the survey to current $\mathrm{AF}$ 210 students while in class.

\section{Treatment of Data}

The questionnaires were collected by the researchers and separated by population. The data for Population A were analyzed separately from Population B data. Comparisons of the information gained from the two populations were then made. The researchers treated the data by tabulating the results using frequency counts and the Spearman's rank correlation coefficient.

\section{Presentation of the Data}

Table 1 shows the number of previous AF 210 students, current AF 210 students, and UAA institution instructors returning surveys. Of the samples surveyed, 38 percent of Population A returned the instructor's questionnaire, and 55 percent of Population B returned the student's questionnaire. Of the previous AF 210 students, only 11 percent returned surveys. Of the current students, 93 percent returned surveys.

\section{ANSWERS TO RESEARCH QUESTIONS}

Research Question One: What are instructors' perceptions of teaching methods used to present aviation human factors materials?

Instructors were given a list of nine teaching methods and asked to rank them in the order that they believed 
were most beneficial to students. Such a ranking was to be accomplished for each of the four subject areas listed.

Instructors responding to the questionnaire represented a wide range of educational. backgrounds and training programs. One had completed an associate degree, two had completed bachelor degree programs, 13 had completed master degree programs, and five had completed doctoral degree programs. Two did not indicate the educational level they had completed. Two instructors who had completed a bachelor degree program indicated they had completed some work toward a graduate degree. Seven respondents who had completed a master degree program indicated they had completed some work toward a doctoral degree. Of the institutions represented, one did not offer a specific aviation degree program of study, four indicated offering an associate degree program in aviation, nine indicated offering bachelor degree programs in aviation, six indicated offering master degree programs in aviation, and three indicated offering doctoral degree programs in aviation.

Of the 23 instructors responding, only 15 contained valid rankings for analysis. Of the eight unusable responses, two contained no indicated teaching methods preferences. One of these indicated that the school was an aviation maintenance school, and the other indicated that the school did not teach aviation human factors. The remaining six contained only partial rankings or check marks by several teaching methods.

Individual instructor rankings (1 through 9) of teaching methods were examined to determine an overall ranking for the teaching methods in the four subject areas listed. A number 1 ranking indicates "most beneficial"; a number 9 ranking indicates "least beneficial." Table 2 presents the summation of these data for each topic taught. The teaching method indicated by respondents as the most beneficial for teaching flight physiology was lecture; for flight psychology, guided group discussion; for aeronautical decision-making, role-play; and for crew resource management, games/simulations. Guided group discussion was identified as the teaching method receiving the most top ranking values from respondents; that is, flight physiology $=2$, flight psychology $=1$, aeronautical decision-making $=3$, and crew resource management $=$ 2.

Research Question Two: What are students' perceptions of teaching methods used to present aviation human factors materials?

Students were given the same list of teaching methods and asked to rank them in order of preference, from most preferred to least preferred. Such a ranking was to be accomplished for each of the four subject areas listed.

Students responding to the questionnaire represented a wide range of flight experience and pilot certification level. The sample included one student pilot, 26 private pilots, and four commercial pilots, all trained in single-engine aircraft. One of the private pilots and all of the commercial pilots were instrument rated. One of the commercial pilots was also multi-engine rated, and one held a certified flight instructor certificate. Five students had logged less than 100 hours of flight time, 18 had logged between 100 and 200 hours, six had logged between 200 and 300 hours, and one had logged between 300 and 400 hours. One student marked two categories.

Table 3 illustrates the overall ranking of teaching method preferences for this group. Of the 31 student responses, only 29 contained valid rankings for preferred teaching methods. The two unusable responses did not rank order the teaching methods. The individual student 
rankings were analyzed to determine an overall student ranking for preferred teaching methods in the four subject areas listed. The preferred teaching method for flight physiology was lecture; for flight psychology, lecture; for aeronautical decision-making, guided group discussion; and for crew resource management, guided group discussion. Guided group discussion was identified as the teaching method receiving the most top ranking values from respondents; that is, flight physiology $=2$, flight psychology $=2$, aeronautical decision-making $=1$, and crew resource management $=1$.

Research Question Three: What is the relationship between student and instructor perceptions of teaching methods used to present aviation human factors materials?

Upon inspection, it is evident that students and instructors agreed that lecture was the preferred teaching method when teaching flight physiology (see Tables 2 and 3 ). In the remaining three subject areas, instructors appeared to indicate as most beneficial those teaching methods that required greater student participation than those indicated by the students.

To determine whether student and instructor perceptions of teaching-methods were in general agreement, the student and instructor rankings for each subject area were analyzed using the Spearman rank correlation coefficient, $r_{\mathrm{s}}$. Table 4 shows the critical values, $r_{0}$ for $\mathrm{n}=9$ rank pairs at various levels of statistical significance (Mendenhall, Scheaffer, \& Wackerly, 1986).

Table 5 shows the correlation coefficients, $r_{\mathrm{s}}$, calculated for each subject area and the critical values at various levels of statistical significance. For each of the four subject areas, a null hypothesis, $\mathrm{H}_{0}$, stated that no association existed between student and instructor perceptions of effective teaching methods. An alternative hypothesis, $\mathrm{H}_{\mathrm{a}}$, stated that there was an association between student and instructor perceptions of effective teaching methods. In order to reject the null hypothesis of no association, $r_{S}$ must be a large positive value (where $-1 \leq \dot{r}_{\mathrm{S}} \leq 1, r_{\mathrm{s}}=-1$ indicates a negative association, and $r_{\mathrm{S}}=1$ indicates a positive association). 
The computed correlation coefficients all exceeded the critical value for the $\alpha=$ .025 significance level. Therefore, the null hypothesis of no association may be rejected at that level. Students and instructors in this sample generally agreed on effective teaching methods used to present all four subject matter areas. It is interesting to note, however, that the agreement appears to be stronger for physiology and psychology. Several factors might be responsible for this difference, including the difference in mean education levels and the instructor's experience in teaching ADM and CRM.

Research Question Four: What materials and equipment do human factors instructors use or feel would be useful in effectively presenting an introductory aviation human factors course?

Instructors were asked to specifically indicate the materials they use in presenting subject matter. The general categories were textbooks, videos, government reports, aviation magazines, professional journals, airline publications, computer programs, facilities/laboratories,

Table 4

Critical Values of Spearman's Rank Correlation Coefficient, $r_{0}$

\begin{tabular}{lllll}
\hline $\mathrm{n}$ & $\alpha=.05$ & $\alpha=.025$ & $\alpha=.01$ & $\alpha=.005$ \\
\hline 9 & 0.600 & 0.683 & 0.783 & 0.833 \\
\hline
\end{tabular}

and other. Of the 23 instructor responses, 20 included a listing of materials they either currently use or would like to use in teaching their courses. These listings ranged from very general to very specific information.

Instructors also were asked to list specific equipment, facilities, and/or laboratories that they would like to have available for teaching their aviation human factors courses. General categories of desired equipment included a library, audiovisual equipment, simulators, computers and related software, physiology training aids, and furniture.

\section{CONCLUSIONS}

Based on the findings reported in this study, the following conclusions may be 
stated:

Instructors indicated that more teacher-centered, didactic teaching methods (lecture, guided group discussion, and demonstration) were most beneficial to students when presenting flight physiology and psychology. Respectively, lecture and guided group discussion were the teaching methods ranked highest by aviation human factors instructors. Instructors also indicated more learner-centered, experiential teaching methods (role-play and games/simulations) were most beneficial to students when presenting $A D M$ and $C R M$. Respectively, role-play and games/simulations were the teaching methods ranked highest among aviation human factors instructors.

Students' first choice of teaching methods indicated that more teacher-centered, didactic teaching methods (lecture and guided group discussion) were most beneficial to them when any of the four subjects were presented. Closer inspection indicates a more learner-centered, experiential teaching method (games and simulations) in second place for ADM and CRM.

Instructor and student preferences for teaching meth- ods are generally in agreement for all subject areas. The agreement does not appear to be as strong for $\mathrm{ADM}$ or CRM.

\section{RECOMMENDATIONS}

Based on the research completed in this study, the following recommendations have been made:

1. Further research should focus on increasing the population size to obtain more representative data, and perhaps to determine the factors that account for differences in preferences among groups.

2. Further research should be accomplished to determine what teaching methods lead to the greatest retention of learned material.

Lorelei E. Miller holds an M.S. in Education and a B.S. in Aviation Management, both from Southern Illinois University at Carbondale. She is a Visiting Lecturer and an Assistant Chief Flight Instructor in the Department of Aviation Management and Flight, College of Applied Sciences and Arts, at Southern Illinois University, Carbondale.

Jose R. Ruiz holds an M.S. in Aeronautical Science from Embry-Riddle Aeronautical University and a B.S. in Human Resource Management from Park College. He is an Assistant Professor in the Department of Aviation Management and Flight, College of Applied Sciences and Arts, at Southern Illinois University, Carbondale.

Susan E. Sharp holds an M.S. in Education and a B.S. in Aviation Air Transportation, both from Northeast Louisiana University. She is an Assistant Professor in the Aeronautical Science Department at Embry-Riddle Aeronautical University. 


\section{REFERENCES}

Archambeault, B. (1993). Holistic mathematics instruction. Adult Learning, 5, 21-23.

Beard, R. L., Salas, E., \& Prince, C. (1995). Enhancing transfer of training: Using role-play to foster teamwork in the cockpit. The International Journal of Aviation Psychology, 5(2), 131-143.

Bowman, T. S. (1993). Pilot judgment and decision-making training in post secondary educational institutions. Unpublished doctoral dissertation, Southern Illinois University, Carbondale.

Chidester, T. R., Helmreich, R. L., Gregorich, S. E., \& Geis, C. E. (1991). Pilot personality and crew coordination: Implications for training and selection. The International Journal of Aviation Psychology, 1(1), 25-44.

Cooke, P. (1987). Role playing. In R. L. Craig (Ed.), Training and development handbook: $A$ guide to human resource development (pp. 430-441). New York: McGraw-Hill.

Davies, I. K. (1981). Instructional technique. New York: McGraw-Hill.

Dismukes, R. K. (1994). Aviation human factors research in U.S. universities: Potential contributions to national needs (NASA Technical Memorandum 108814). Moffett Field, CA: NASA-Ames Research Center.

Federal Aviation Administration. (1977). Aviation instructor's handbook (Advisory Circular 60-14). Washington, DC: Author.

Federal Aviation Administration. (1987). Aeronautical decision making for students and private pilots (FAA Report No. PN-86/41). Washington, DC: Author.

Federal Aviation Administration. (1997a).97FARAIM: Federal aviation regulations and aeronautical information manual. Newcastle, WA: Aviation Supplies and Academics.

Federal Aviation Administration. (1997b). Commercial pilot practical test standards for airplane (SEL, MEL, SES, MES) (FAA Publication No. FAA-S-8081-12). Washington, DC: Author.

Federal Aviation Administration. (1998). 98FARAIM: Federal aviation regulations and aeronautical information manual. Newcastle, WA: Aviation Supplies and Academics.

Foushee, H. C., \& Helmreich, R. L. (1988). Group interaction and flight crew performance. In E. L. Wiener \& D. C. Nagel (Eds.), Human factors in aviation (pp. 189-227). San Diego, CA: Academic Press.

Galbraith, M. W. (1994). Connecting instructional principles to self-esteem. Adult Learning, 5, 24-25, 31.

Gropper, G. L., \& Ross, P. A. (1987). Instructional design. In R. L. Craig (Ed.), Training and development handbook: $A$ guide to human resource development (pp. 195-216). New York: McGraw-Hill.

Hawkins, H. F. (1987). Human factors in flight (2nd ed.). Brookfield, VT: Ashgate.

Heinrich, R., Molenda, M., \& Russell, J. D. (1993). Instructional media and the new technologies of instruction (4th ed.). New York: Macmillan.

Helmreich, R. L., \& Wilhelm, J. A. (1991). Outcomes of crew resource management training. The International Journal of Aviation Psychology, 1(4), 287-300.

Mendenhall, W., Scheaffer, R. L., \& Wackerly, D. D. (1986). Mathematical statistics with applications (3rd ed.). Boston: Duxbury.

Nickerson, R. S. (Ed.). (1995). Emerging needs and opportunities for human factors research. Washington, DC: National Academy Press.

Reinhart, R. O. (1996). Basic flight physiology (2nd ed.). New York: McGraw-Hill.

Roscoe, S. N., Jensen, R. S., \& Gawron, V. J. (1980). Introduction to training systems. In S. N. Roscoe (Ed.), Aviation psychology (pp. 173-181). Ames, IA: Iowa State University Press.

Weston, C., \& Cranton, P. A. (1986). Selecting instructional strategies. Journal of Higher Education, 1(3), 259-288. 